\title{
The Effect of Amino Acids Lysine and Methionine on the Carcass of Native Chickens
}

\author{
I Nengah Andri Bayu Dita*, Ni Ketut Sri Rukmini, Ni Made Yudiastari \\ Department of Animal Husbandry, Faculty of Agriculture, Warmadewa University, \\ Denpasar, Bali, Indonesia \\ * E-mail: nengahandri02@gmail.com
}

\begin{abstract}
This study aims to determine the effect of $1 \%$ lysine, $0.5 \%$ methionine, and the combination of lysine and methionine $(1 \%+0.5 \%)$ in the ration on the weight gain of carcass parts of chickens. The design used in this study was a completely randomized design (CRD) consisting of 4 treatments and 3 replications, while the treatments were RO (control) native chickens that were not given additional lysine and methionine, RI native chickens were given feed containing lysine 1\%, R2 of free-range chickens given feed containing 0.5\% methionine, $R 3$ of native chickens given feed containing lysine and methionine $(1 \%+0.5 \%)$. The parameters observed were the weight gain in the chest, thighs, wings, and back. The data obtained were analyzed by analysis of variance. The results showed that the provision of rations which were added with the combination of amino acid lysine and methionine had a very significant effect $(P>0.01)$ on the weight gain of the carcass, thighs, and backs of native chickens aged 10 weeks. Based on the results of this study it can be concluded that the combination of the amino acids lysine and methionine in the ration gave the best effect on the weight gain of carcass parts of native chicken aged 10 weeks. Based on the results of the study, it is suggested to add the combination of lysine (1\%) and methionine $(0.5 \%)$ in the native chicken ration.
\end{abstract}

Keywords: native chickens, carcass weight, lysine, methionine

\section{Introduction}

Native chicken is a local Indonesian chicken with a fairly high population and is spread throughout Indonesia with the production of meat and eggs which play a role in supporting the needs of animal protein [1]. Native chicken has the potential for meat and eggs that are not yet optimal, this is evidenced by the lack of attention to the quality of the ration given in maintenance, the ration given has a low protein content, so that the nutrient needs of native chickens are not fulfilled, this problem can be overcome by increasing the protein content in rations that are assessed from the balance and composition of amino acids, but not all rations contain appropriate protein because rations containing appropriate protein are expensive, so it is necessary to add synthetic amino acids which can increase the efficiency of using the ration according to [2].

Generally, poultry feed derived from vegetable products has a deficiency of amino acids Lysine and Methionine, so it needs to be supplemented into feed in the form of synthetic amino acids. The amino acids that are most difficult to complete in balance are Lysine, Methionine, Cystine, and Tryptophan.

These amino acids are called essential amino acids that need to be given to meet needs when compiling rations [3]. Lysine is only found in animal-based feed ingredients, while the composition of the ration generally comes from vegetable feed ingredients, so the ration lacks lysine and needs to be added with lysine in the form of synthesis. Local feed ingredients that are deficient in essential amino acids can be overcome by supplementing with synthetic amino acids to increase the efficiency of feed use in the metabolism of food substances [4]. Sources of essential amino acids are lysine and 
methionine. Based on the foregoing, a study aimed to determine the effect of lysine $1 \%, 0.5 \%$ methionine, and a combination of lysine and methionine $(1 \%+0.5 \%)$ in the ration on the weight gain of chicken carcass parts.

\section{Material and Methods}

\section{Research design}

The design used in this study was a completely randomized design (CRD) consisting of 4 treatments and 3 replications, while the treatments were R0 (control) native chickens that were not given additional lysine and methionine, R1 native chickens were given feed containing lysine $1 \%$, R2 of native chickens given feed containing $0.5 \%$ methionine, R3 of native chickens given feed containing lysine and methionine $(1 \%+0.5 \%)$, Each treatment received 3 replications, so there were 12 plots and each in one plot consists of 5 native chickens, and 60 native chickens are used.

\section{Location and Time of Research}

This research was conducted at Sedap Malam Street, located in Kelurahan Kesiman, Denpasar City, and was conducted for 10 weeks, from 14 October to 23 December 2019.

\section{Research Material}

The chickens used were native chickens without the separation of male and female 3 weeks old, had relatively homogeneous weight, with a bodyweight range of 154.4-190.6 gram. There were 60 native chickens used in the study.

\section{Research variable}

The variables observed in this study included carcass weight at the breast, wing carcass weight, thigh carcass weight, and dorsal carcass weight. The data obtained were analyzed using a variance, and if the results were significantly different $(\mathrm{P}<0.05)$ and continued with the small real distance test from Duncan.

\section{Results and Discussion}

Based on the results of the study in Table 1, the amino acid treatment in the 10-week old native chicken ration showed a statistically insignificant difference $(\mathrm{P}>0.05)$ on the weight of the breasts, wings, thighs, and back, for treatment R0, R1, and R2.

Treatment R3 (lysine 1\% and methionine 0.5\%) had the highest weight of the carcass parts of the thorax, wings, thighs, and back and was significantly different $(\mathrm{P}<0.01)$ except for the wings. This shows that the limit for giving amino acids in the ration of free-range chickens aged 10 weeks is lysine $(1 \%)$ and methionine $(0.5 \%)$. By providing levels of lysine $(1 \%)$ and methionine $(0.5 \%)$ the body of the chicken can digest and decompose the rations consumed properly. According to [5], the Provision of the amino acids methionine and lysine can accelerate growth in native chickens to achieve maximum growth. So that the addition of lysine and methionine in the native chicken ration affects the carcass weight of native chickens. Amino acids methionine and lysine are the 2 main limiting amino acids in corn and soy-based feed for broiler chickens. This is possible if free-range chickens are given additional amino acids methionine and lysine to improve their performance. Lysine supplementation in feed lacking lysine can balance the amino acids which function to modify the amount of protein synthesized and degraded in chickens [5]. 
Table 1

Average Weight of the Parts of Village Chicken Carcasses Given Rations Containing Lysine and Methionine

\begin{tabular}{cccccc}
\hline Variable & \multicolumn{4}{c}{ Treatment } & SEM \\
\cline { 2 - 5 } & R0 & R1 & R2 & R3 & \\
\hline Chest (g) & $70.43^{\mathrm{b}}$ & $72.63^{\mathrm{b}}$ & $73.80^{\mathrm{b}}$ & $109.27^{\mathrm{a}}$ & 3.61 \\
Wing (g) & $47.80^{\mathrm{a}}$ & $50.10^{\mathrm{a}}$ & $53.00^{\mathrm{a}}$ & $61.67^{\mathrm{a}}$ & 2.05 \\
Thigh (g) & $104.87^{\mathrm{b}}$ & $111.73^{\mathrm{b}}$ & $107.77^{\mathrm{b}}$ & $145.87^{\mathrm{a}}$ & 3.64 \\
Back (g) & $72.57^{\mathrm{b}}$ & $72.10^{\mathrm{b}}$ & $79.13^{\mathrm{b}}$ & $107.07^{\mathrm{a}}$ & 3.26 \\
\hline
\end{tabular}

Information :

- Values with the same letter on the same row show no significant difference $(\mathrm{P}>0.05)$.

- SEM (Standard Error of The Treatment Means).

Table 1 also shows that $\mathrm{R} 1$ treatment (lysine 1\%) has no significant effect $(\mathrm{P}>0.05)$ on the variables of the chest, wing, thigh, and back weight. However, the R1 treatment tended to have a higher weight than the R0 treatment (control), this was because the amino acid lysine needs were met in the chicken ration. The provision of feed containing the aminoacid lysine balance with metabolic energy of 2.9-3.3 Kcal/kg in free-range chickens aged 0-12 weeks improved the feed conversion from 4.7 to 4.3 , whereas at 13-22 weeks of age lysine amino acid balance and metabolic energy from 2.8 to $3.0 \mathrm{Kcal} / \mathrm{kg}$ improved feed conversion from 7.7 to 7.3 [6]. Lysine supplementation in feed lacking lysine can balance the amino acids which function to modify the amount of protein synthesized and degraded in chickens [5].

Treatments R0, R1, and R2 showed no significant difference $(\mathrm{P}>0.05)$ on the variables of the weight of the chest, wings, thighs, and back. However, treatment R0 (control) resulted in lower weight of the carcass of the chest, wings, thighs, and back compared to other treatments. This occurs because the ratio is deficient in essential amino acids. [7] stated that chicken body weight is influenced by the availability and balance of amino acids in the feed it consumes. The amino acids methionine and lysine play a role in the growth of chicken body tissue. There is a deficiency of lysine in chickens, it will cause weight loss and stunted growth. Therefore, the addition of lysine to rations that are deficient in lysine can improve the quality of the ration [8]. The low productivity of native chickens is influenced by several factors including age and feed. The feed is one of the important factors to increase the productivity of native chickens, both carcass and non-carcass production, if given good feed with nutrient content of food substances that are following basic living needs, it can increase the live weight gain of native chickens faster [9].

The $\mathrm{R} 2$ treatment $(0.5 \%$ methionine) showed no significant difference $(\mathrm{P}>0.05)$ on the variable weight of the thighs, chest, wings, and back. However, treatment R2 has a higher weight than treatment R1 and R0. According to [10], a basic ration prepared from corn and soybean meal with low protein content requires the addition of methionine to the ration, because the amino acid methionine is the limiting amino acid in the ration. This statement is by [11], that supplementing essential amino acids into rations with low protein content would support chicken performance. It is also strengthened by [12] who reported their research results, that rations containing $19.1 \%$ crude protein,

Treatment of R0 (control) on the variable wing weight showed insignificant differences $(\mathrm{P}>0.05)$ decreased compared to treatments R1, R2, and R3 (Table 1). Wing weight at R0 $47.80 \mathrm{~g} /$ head has 
decreased compared to R1, R2, and R3. This is because the carcass weight at treatment R0 is the lowest which results in a low wing weight as well. Wings are part of the carcass that contains more bone tissue than muscle tissue [13]. The highest wing weight was obtained by R3 treatment with a weight of $61.67 \mathrm{~g} /$ head. There is a close relationship between carcass weight and carcass parts, reinforced by [14] that carcass parts are directly determined by carcass weight [15].

\section{Conclusion}

The combination of the amino acids lysine and methionine in the rations of native chickens aged 10 weeks was significantly different $(\mathrm{P}>0.01)$ on the weight of the carcass parts of the breasts, thighs, and back. Treatment R3 (lysine 1\% and methionine 0.5\%) had the highest carcass weight on the chest, wings, thighs, and back and was significantly different from other treatments. It is recommended to give amino acids to the ration of native chickens aged 10 weeks, namely lysine $(1 \%)$ and methionine $(0.5 \%)$.

\section{Acknowledgments}

The author would like to thank all those who have helped and completed the research until the writing of this article.

\section{Reference}

[1] Permana, PA, VD Yunianto, and U. Atmomarsono, (2014). The Effect of Protein and Ration Lysine Levels on the Production Performance of Kampung Chickens. Animal Agriculture Journal 3 (2): 113-120

[2] Mariandayani, HN, Darwati, S., Sutanto, E., and E. Sinaga. (2017). Increasing Productivity of Local Chickens through Crossing of Three Clumps of Local Chickens in the Second Generation. Proceedings of the 2017 National Biology Seminar, Biology Education for the Future of the Earth, Department of Biology Education, Syiah Kuala University. pp. 139-146

[3] Anggorodi, R. (1985), General Forage Science. Publisher PT Gramedia Jakarta

[4] Zainuddin, D., and R. Jannah. (2003). Supplementation of the amino acid lysine in the basal ration for laying native hens on egg weight, egg index, sprouting, and hatchability and their correlation. National Workshop on Local Chicken Development Technology Innovation, Ciawi Animal Research Institute, Bogor.

[5] Pesti, GM, RI Bakalli, JP Driver, A. Atencio, and EH Foster. (2005). Poultry Nutrition and Feeding. Department of Poultry Science, University of Georgia. Trafford Publishing. Athens.

[6] Resnawati, H., and A. Sinurat (1997). Research Report on Fiscal Year 1987/1988. Commodity Gas. Ciawi Animal Research Institute, Bogor.

[7] Cafe, MB, and PW Waldroup. (2006). Interactions between levels of methionine and lysine in broiler diets changed at typical industry intervals. Int. J. Poultry Sci. 5 (11): 1008-1015

[8] Nuraini, A. Yuniza, and S. Hafiz, (2011). The Effect of Lysine Addition in Rations on Live Weight, Carcass and Carcass Pieces of Village Chickens Indonesian Animal Husbandry Journal, 13 (3) ISSN 1907-1760

[9] Hidayat, C., Sumiati., And S. Iskandar. (2015). Percentage of Carcass Weight and Commercial Cuts of Sentul-G3 Chickens Given Rations Containing High Bran with Phytase and ZnO Supplementation. Indonesian Journal of Agricultural Sciences. 20 (2): 131-140.

[10] Auyagi, S, and DK Baker, (1993). Nutritional evaluation of Copper-Methionine complex for chicks. Poultry Sci. 72: 2309 - 2315

[11] Novacek, EJ, and CW Carlson, (1969). Low protein cage-layer diets and amino acids. Poultry Sci. 48: 1490-1497 
[12] Charles VL, Wihandoyo, Zuprizal, and Sri Harimurti. (2018). The Effect of Dl-Methionine and L-Lysine Hcl Supplementation in Cafeteria Standard Feed on Body Weight, Internal Organs, and Reproductive Organs of Kampung Chickens in Pullet Phase. Integrated Animal Science Journal Vol. 6 (2): 128-133

[13] Basoeki, BDA (1983). Effect of level of tofu dregs application in ration on commercial carcass pieces of female broiler hybrid strain aged 6 weeks. Essay. Faculty of Animal Husbandry. Bogor Agricultural Institute, Bogor

[14] Widhiarti, (1987). Effect of Energy Levels and Feed Protein Levels on Performance, Carcass, and Abdominal Fat at several Age Levels of Broiler Chickens. Scientific work. Faculty of Post-Graduate UGM, Yogyakarta

[15] Rasyaf, M. (2011). Guide to Breeding Broilers. Self-Help Spreader. Jakarta Journal of Animal Husbandry Research and Innovation Vol 2 (1): 26-31 